\title{
Pancake kidney: an incidental finding in a young man
}

\author{
Pranav Mohan Singhal, Manu Vats, Mehul Agarwal, Sushanto Neogi
}

General Surgery, Maulana Azad Medical College, New Delhi, India

\section{Correspondence to Dr Manu Vats,}

vatsmanu@gmail.com

Accepted 13 September 2018

\section{DESCRIPTION}

An 18-year-old man presented to the surgery emergency department with signs and symptoms of acute intestinal obstruction. There was a previous history of exploratory laparotomy for intestinal obstruction 8 years ago. Abdominal examination revealed a healthy transverse scar in the right lumbar region extending to the umbilical region, abdominal distension and no tenderness or guarding. The patient was managed conservatively by nasogastric tube decompression and intravenous fluids support. A contrast-enhanced computed tomography (CECT) of the abdomen was done. The patient responded well to the conservative management, and the intestinal obstruction was relieved. The CECT abdomen reported an ectopic location of bilateral kidneys, lying in the lower abdomen. The kidneys were para-median in location and extending between L4 and S2 vertebrae. Upper and mid-pole of both kidneys were fused across the midline (figures 1 and 2). No evidence of any calculus or hydronephrosis was seen. Opacification of bilateral pelvicalyceal system and ureters was noted on delayed images.

An ectopic kidney results from an improper ascent during development. The pancake kidney (PK) aberration results from complete medial fusion of the

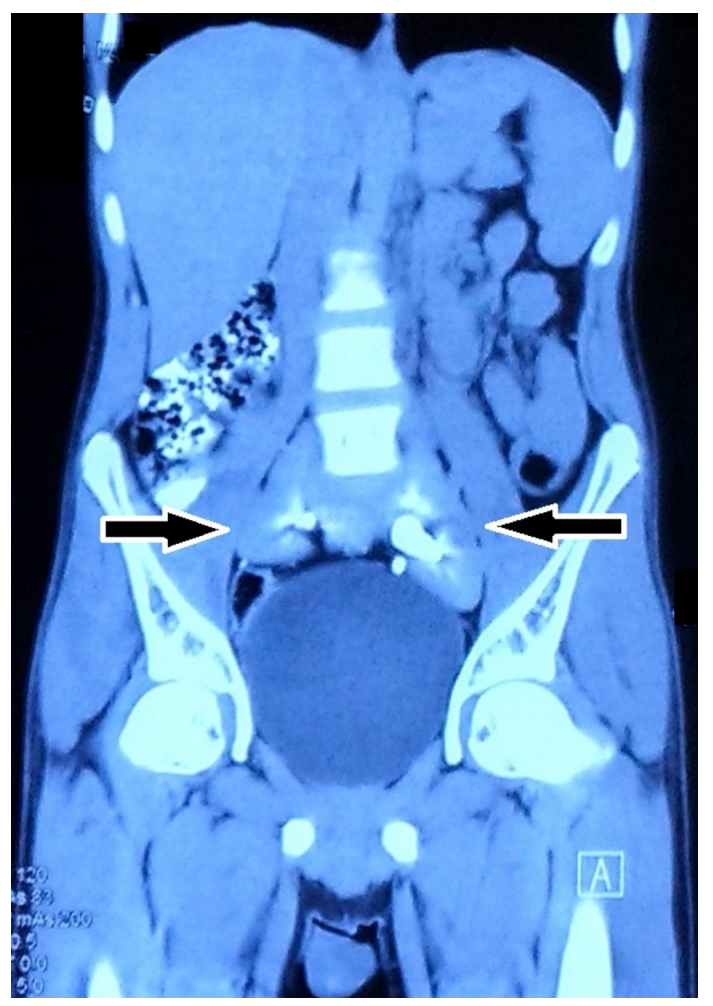

Figure 1 CECT abdomen coronal section showing fused 'pancake' kidney in pelvis (solid arrows). CECT, contrastenhanced CT.

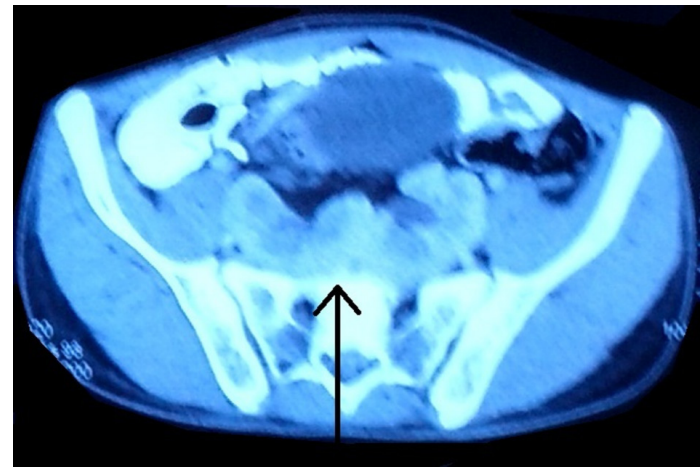

Figure 2 CECT abdomen transverse section showing the fused medial poles of the two kidneys in pelvis (solid arrow). CECT, contrast-enhanced CT.

metanephric blastema at an early stage of embryonic development and is characterised by a single, flat, non-reniform mass, in a medial position within the pelvic cavity or at the level of the aortic bifurcation. ${ }^{1}$

The most extreme form of renal fusion is the PK, which contributes to less than $10 \%$ of all renal fusion anomalies. ${ }^{2}$ There is a characteristic extensive fusion of the superior and inferior poles of both kidneys across the entire medial aspect with the isthmus being absent. The pelvis is anteriorly placed, and the ureters remain uncrossed. Each collecting system drains its respective half of the kidney and does not communicate with the opposite side. Such kidney may also be referred as a pancake, disc, doughnut, cake or a shield kidney. Patients with PK are usually asymptomatic but may present with features of urinary tract infection, fever and vague lower abdominal pain as they are more predisposed to urinary stasis and obstruction.

Patients having renal fusion anomalies are more likely to develop renal malignancies like Wilms tumour, renal cell carcinoma and rhabdomyosarcoma. Available literature shows that the probability of development of Wilms tumour in a patient with horseshoe kidney is almost twice as that compared with the population with normal renal anatomy. However, due to the scarcity of reported cases of $\mathrm{PK}$, the risk of development of Wilms tumour in

\section{Learning points}

- Pancake kidney is an extremely rare congenital renal fusion disorder.

- The diagnosis of pancake kidney is usually an incidental one, and unless the patient is symptomatic, a conservative approach is pursued.

- Individuals with pancake kidney have a higher incidence of neoplasms; therefore, periodic regular follow-up is advisable. 
these patients cannot be conclusively ascertained. Hence, a plan for follow-up and screening of patients with PK for tumours is not available. In asymptomatic patients, surgical intervention is usually not required; however, periodic follow-up may be advisable due to the increased risk of malignancies. Surgical procedures, if warranted, are often challenging because of anomalous vessels, and urological expertise is indispensable. ${ }^{3}$

Acknowledgements The authors would like to thank the Department of Radiology, Maulana Azad Medical College and Lok Nayak Hospital.

Contributors PMS and MV conceived the manuscript. PMS prepared the manuscript. MA provided the images. SN edited the manuscript. SN and MV reviewed the manuscript. All the authors read and approved the final draft.
Funding The authors have not declared a specific grant for this research from any funding agency in the public, commercial or not-for-profit sectors.

Competing interests None declared.

Patient consent Obtained.

Provenance and peer review Not commissioned; externally peer reviewed.

\section{REFERENCES}

1 Maranhão CPM, Miranda C, Santos CJJ, et al. Congenital upper urinary tract abnormalities: new images of the same diseases. Radiol Bras 2013;46:43-50.

2 Glodny B, Petersen J, Hofmann KJ, et al. Kidney fusion anomalies revisited: clinical and radiological analysis of 209 cases of crossed fused ectopia and horseshoe kidney. BJU Int 2009:103:224-35.

3 Rac G, Ellet JD, Sarkissian H, et al. Open Partial Nephrectomy for Wilms' Tumor in a Cross-fused Pelvic Ectopic Kidney. Urology 2016;93:188-90.

Copyright 2018 BMJ Publishing Group. All rights reserved. For permission to reuse any of this content visit http://group.bmj.com/group/rights-licensing/permissions.

BMJ Case Report Fellows may re-use this article for personal use and teaching without any further permission.

Become a Fellow of BMJ Case Reports today and you can:

- Submit as many cases as you like

- Enjoy fast sympathetic peer review and rapid publication of accepted articles

- Access all the published articles

- Re-use any of the published material for personal use and teaching without further permission

For information on Institutional Fellowships contact consortiasales@bmjgroup.com

Visit casereports.bmj.com for more articles like this and to become a Fellow 